Division of Geological \& Geophysical Surveys

PRELIMINARY INTERPRETIVE REPORT 2009-2

\title{
REINTERPRETATION OF THE KALOA DEPOSITS NEAR GRANITE POINT, NORTHWESTERN COOK INLET, ALASKA
}

\author{
by \\ Richard D. Reger
}

February 2009

THIS REPORT HAS NOT BEEN REVIEWED FOR TECHNICAL CONTENT (EXCEPT AS NOTED IN TEXT) OR FOR CONFORMITY TO THE EDITORIAL STANDARDS OF DGGS.

Released by

STATE OF ALASKA

DEPARTMENT OF NATURAL RESOURCES

Division of Geological \& Geophysical Surveys 3354 College Rd.

Fairbanks, Alaska 99709-3707 



\section{CONTENTS}

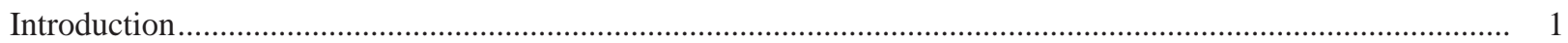

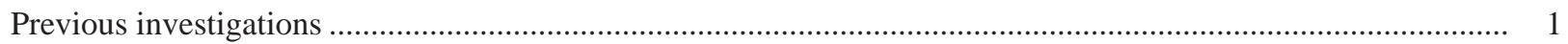

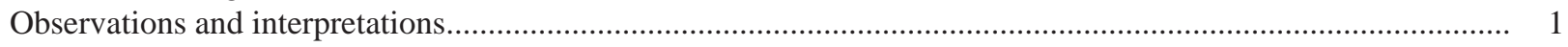

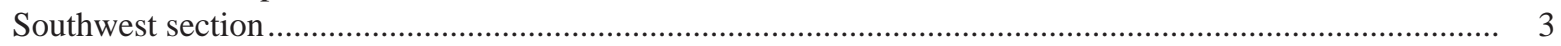

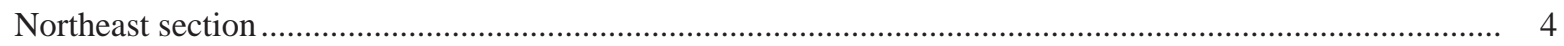

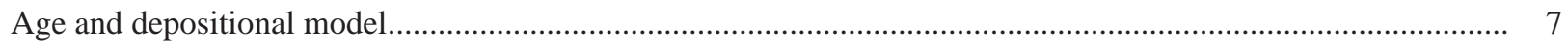

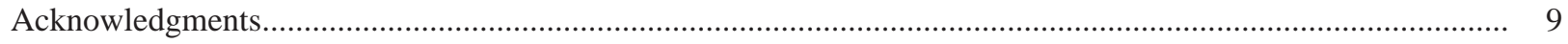

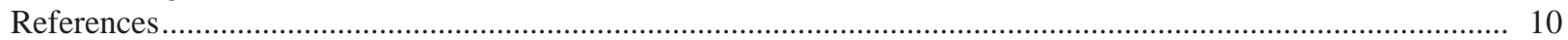

\section{FIGURES}

Figure 1. Maps showing location of Kaloa section and petroleum operations in the Granite Point area, south-central Tyonek A-4 Quadrangle, Alaska

2. Photograph showing lines of cobbles between diamictons in coastal bluff at Granite Point delineating lags formed by scouring of the former inlet floor by bottom currents

3. Photograph showing lens of dark-gray, angular, scoriaceous andesite cobbles and pebbles in coastal bluff at Granite Point

4. Sketch of section exposed northeast of pipeline centerline in coastal bluff at Granite Point .....

5. Photograph showing prominent coal bed exposed in coastal bluff northeast of pipeline centerline. Inset shows intensely fractured, pulverized, and distorted allochthonous coal mixed with pebble diamicton......

6. Annotated photograph showing principal stratigraphic units exposed in coastal bluff partially obscured by slope colluvium ....

7. Annotated photograph showing 30-cm-thick, fine to medium tan sand containing clasts of siderite overlying a tan-gray, complexly bedded pebbly sand, silt, and dropstone diamicton sandwiched between massive, medium-gray dropstone-rich diamictons......

8. Photograph showing the coastal bluff at the southwestern end of Beshta Bay displaying complexly deformed diamictons interlayered with sand beds

9. Sketch showing environment beneath fluctuating tidewater glaciers and ice shelves during deposition of Kaloa sediments on the western flank of the growing Granite Point anticline between Granite Point and Beshta Bay 



\title{
REINTERPRETATION OF THE KALOA DEPOSITS NEAR GRANITE POINT, NORTHWESTERN COOK INLET, ALASKA
}

\author{
by \\ Richard D. Reger ${ }^{1}$
}

\section{INTRODUCTION}

The origin and age of the Kaloa deposits exposed in the coastal bluff in the vicinity of Granite Point in northwestern Cook Inlet are controversial. This report briefly reassesses the stratigraphic section at Granite Point, incorporating depositional models for diamictons that have proven appropriate elsewhere in the Cook Inlet basin, and placing the section in the glacial chronology of the Cook Inlet basin.

\section{PREVIOUS INVESTIGATIONS}

Schmoll and Yehle (1978, fig. 38) initially mapped deposits in the Granite Point area as older morainal deposits of Pleistocene age. Later, Schmoll and others (1984, p. 53-64) described and illustrated the 110-m-thick stratigraphic package exposed in the coastal bluff between Granite Point and Beshta Bay, stressed its unique character compared to other coastal-bluff exposures around Cook Inlet, and informally named the Kaloa deposits after a nearby well, although they did not explain how the exposed section relates to the well. Even though a fundamental unresolved issue in their evaluation was the allochthonous versus autochthonous origin of the coal prominently displayed in the coastal bluff, on the basis of the presence of late Miocene pollen in the coal Schmoll and others (1984, p. 62) favored an autochthonous origin, correlated the coal with the nearby Beluga Formation, and favored a Tertiary age for the Kaloa deposits. Further, they suggested that the diamictons that dominate the bluff face could correlate with subsurface 'tillites' identified by Boss and others (1976) in wells penetrating the Sterling and Beluga Formations in the northern Kenai Peninsula to the east and could be evidence for multiple glaciation of late Tertiary age in the Cook Inlet basin.

Haeussler and others (2000) favored an allochthonous origin for the prominent coal bed at Granite Point, emphasizing that the coal lacks depositional contacts, is sheared along its margins, and consists of internally disrupted and randomly oriented coal clasts. As they pointed out, the presence of scattered coal clasts in the diamictons clearly indicates that the coals were lithified prior to deposition of the diamictons, implying a considerable difference in age, and they concluded that the Kaloa deposits are Pleistocene in age.

\section{OBSERVATIONS AND INTERPRETATIONS}

The coastal bluff in which the Kaloa deposits are exposed stands 40 to $43 \mathrm{~m}$ above the beach from Granite Point northeastward for $1.5 \mathrm{~km}$ to Beshta Bay in the south-central Tyonek A-4 Quadrangle (fig. 1). The Kaloa deposits are dominated by a succession of medium- to dark-gray autochthonous diamictons with variable dropstone contents. A younger, distinctive tan-gray to medium-gray diamicton of fairly uniform thickness in the uppermost 4 to $7 \mathrm{~m}$ of the bluff was identified as drift of the Nikolai ground moraine by Schmoll and others (1984, fig. 9A) and was considered to be either middle Wisconsinan or middle late Wisconsinan in age (Schmoll and Yehle, 1986). The upper meter or so of this diamicton consists of rippled sands and tidal silts, indicating shallow inlet conditions. Discontinuously capping the bluff is a 1- to 2-m-thick freshwater peat, which has a mean calibrated basal radiocarbon age of 14,304 yr B.P. (Beta-97627, Haeussler and others, 2000, table 2). The apparent dip of the Kaloa deposits in the plane of the bluff face is as shallow as $\sim 2-4^{\circ}$ southwest in the southwestern portion of the bluff and as much as $\sim 6-7^{\circ}$ southwest in the northeastern portion of the bluff. Thus, older Kaloa units crop out close to Beshta Bay and progressively younger Kaloa units are exposed southwestward along the coast.

The bluff section is divided in half by a prominent gully traversed by a petroleum pipeline that connects storage and pumping facilities on the west side of Cook Inlet with refineries at Nikiski on the northwestern Kenai Peninsula (Magoon and others, 1976, pl. 1) (fig. 1). Southwest of this gully, the coastal-bluff section is fairly simple. A more complex coastal-bluff section is exposed northeast of the gully. A fairly continuous colluvial apron along the toe of the bluff complicates mapping and interpretation of the lowermost strata.

${ }^{1}$ Reger's Geologic Consulting, P.O. Box 3326, Soldotna, AK 99669-3326 


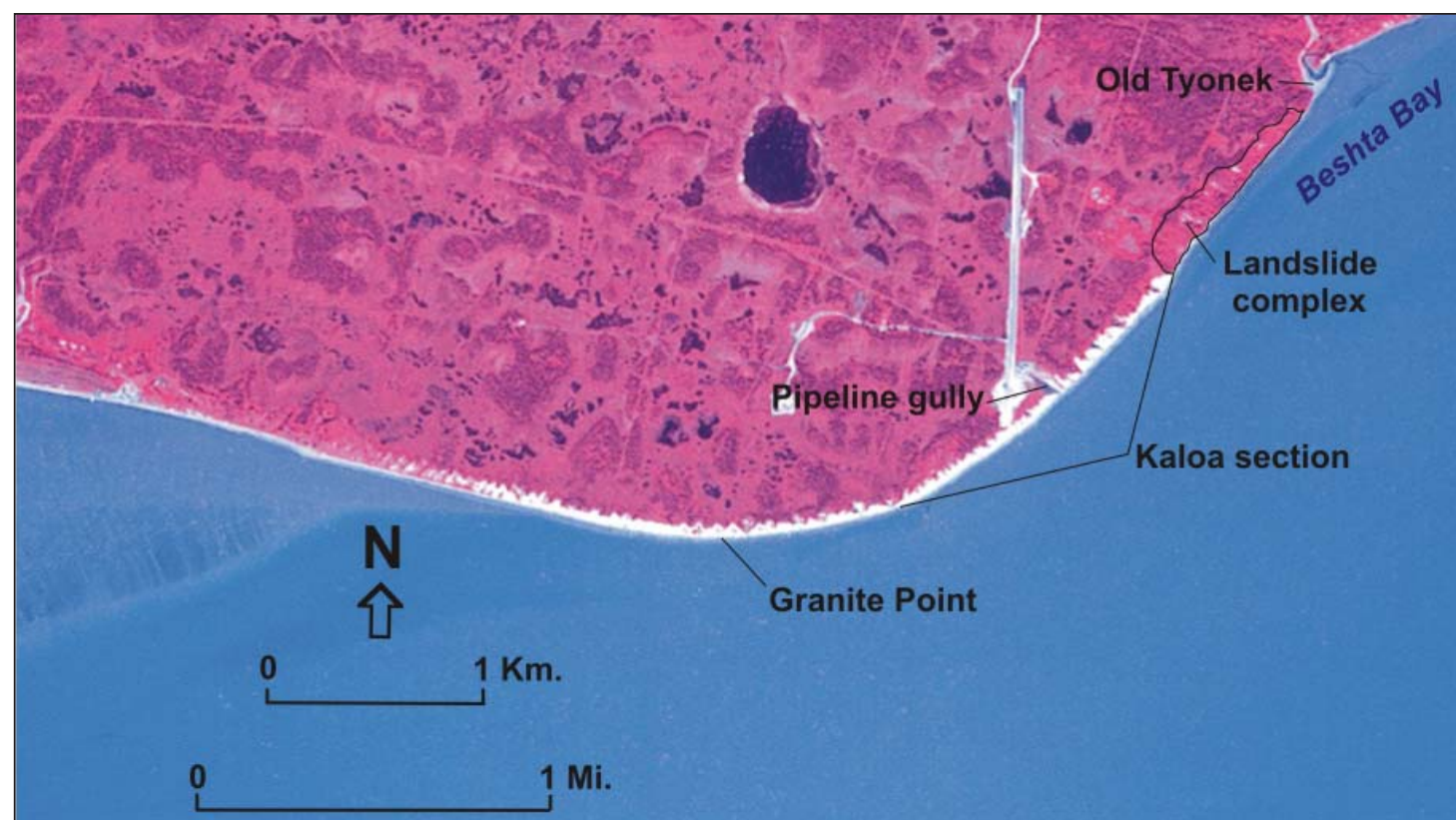

\section{Platform Bruce}

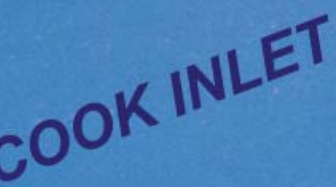

\section{Platform Anna $\rightarrow$}

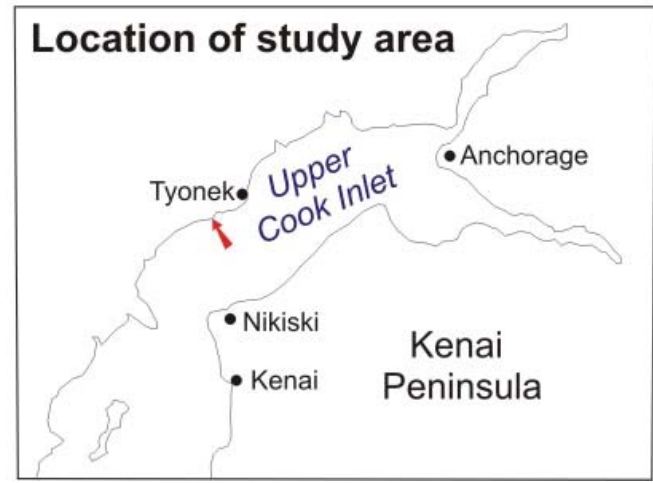

Figure 1. Location of Kaloa section and petroleum operations in the Granite Point area, south-central Tyonek A-4 Quadrangle, Alaska. 


\section{SOUTHWEST SECTION}

The southwestern coastal bluff consists almost entirely of medium-gray autochthonous diamictons associated with numerous lines of dropstones that mark the intersection of the bluff face with lags left on the former inlet floor by bottom-scouring currents that were probably active beneath floating glacial ice (Eyles and McCabe, 1989, fig. 7-4) (fig. 2). Dropstones, dominantly of volcanic and granitic lithologies derived from the Alaska Range to the northwest, vary in abundance and reach a maximum diameter of $\sim 2 \mathrm{~m}$. A 0.8-m-thick dark-gray lens surrounded by medium-gray diamicton is conspicuously visible slightly below the midpoint of the bluff face $\sim 180 \mathrm{~m}$ southwest of the pipeline gully (fig. 3). This lens consists of angular scoriaceous andesite cobbles and pebbles in a dark-gray (2.5YR3/0) matrix of medium to coarse sand with angular grains. Schmoll and others (1981, p. 104) identified this lens as a volcaniclastic deposit of probable late Tertiary age and suggested that volcaniclastic deposits may have been much more widespread in the northwestern Cook Inlet basin than previously mapped. Because of its unique lithology, limited extent, and the conformity with nearby cobble lags, I interpret this lens as an andesite dropstone that broke apart during or after deposition on the inlet floor. Numerous angular cobbles and boulders of clastic coal are among dropstones scattered throughout the diamictons exposed in the bluff face.

\section{NORTHEAST SECTION}

The northeast section is dominated by numerous medium-gray diamictons, which are mostly dropstone rich, but lines of dropstones are generally absent. The lower bluff is traversed by a conspicuous dark-gray layer of allochthonous coal that pinches out $\sim 265 \mathrm{~m}$ northeast of the pipeline centerline (fig. 4). Although the 1.5- to 2m-thick coal looks like a coherent bed from a distance, its allochthonous origin is clearly demonstrated by the intensely fractured nature of the bed, which is composed of angular, blocky to platy chunks of coal up to $30 \mathrm{~cm}$ in diameter, pieces of coherent sandstone (some with fragments of coalified fossil wood that are typical of channel

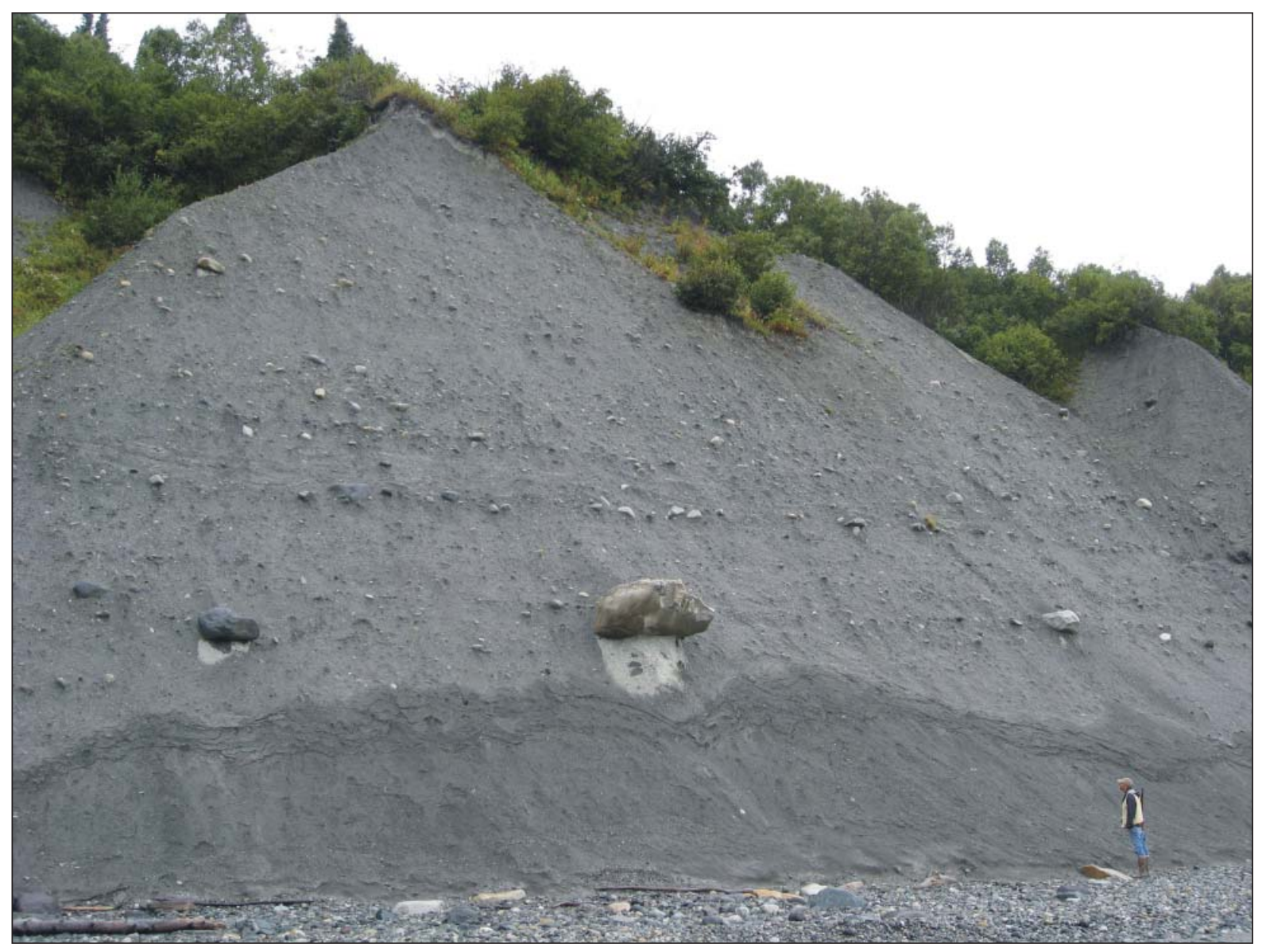

Figure 2. Lines of cobbles between diamictons $\sim 300 \mathrm{~m}$ southwest of pipeline centerline in coastal bluff at Granite Point delineate lags formed by scouring of the former inlet floor by bottom currents. Person provides scale. Photograph taken 08/23/07 by Dave LePain. 


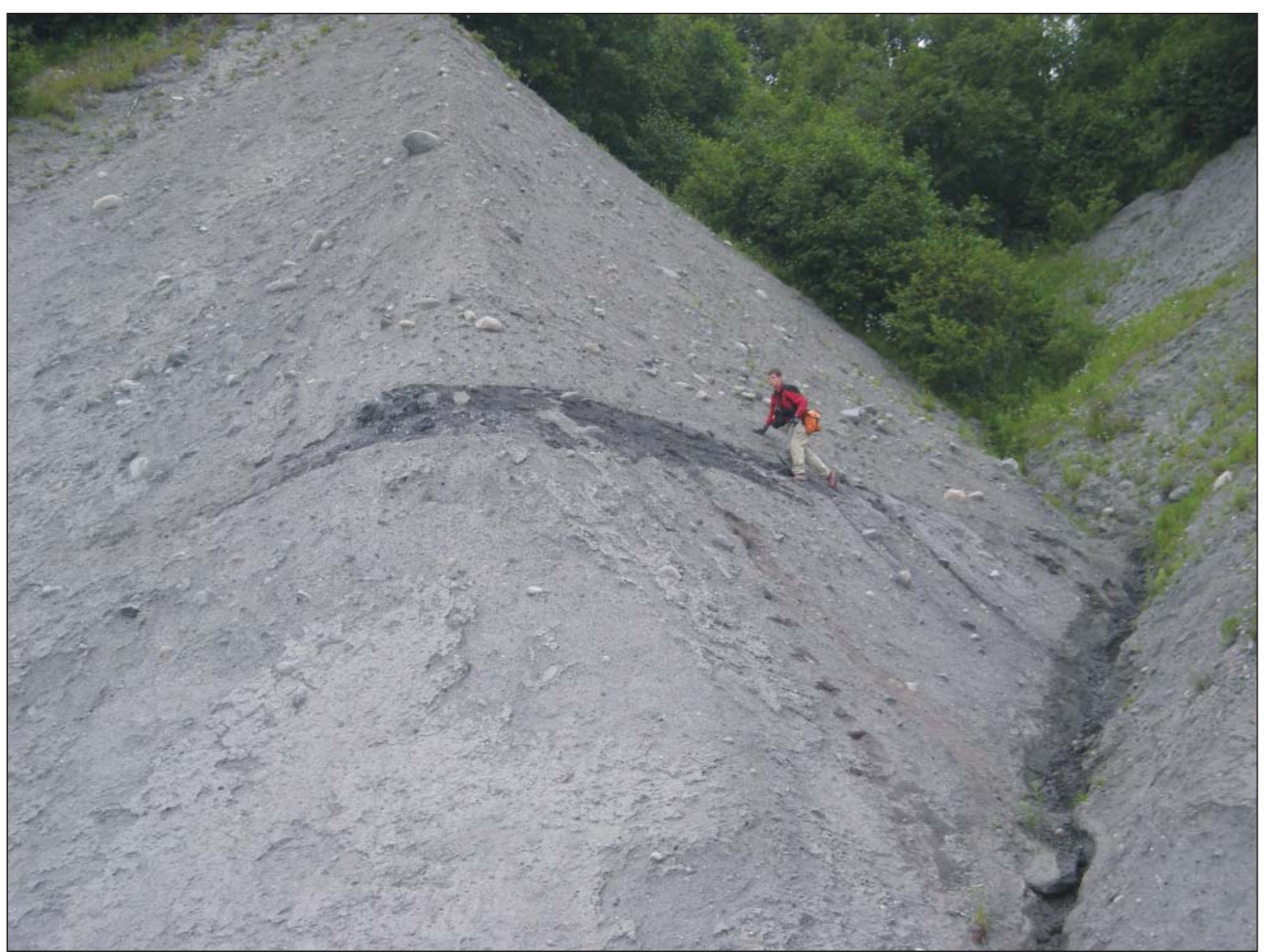

Figure 3. Lens of dark-gray, angular, scoriaceous andesite cobbles and pebbles in a dark-gray sand matrix surrounded by medium-gray dropstone-rich diamictons in coastal bluff at Granite Point $180 \mathrm{~m}$ southwest of pipeline centerline. Person provides scale. Photograph taken 07/16/08.

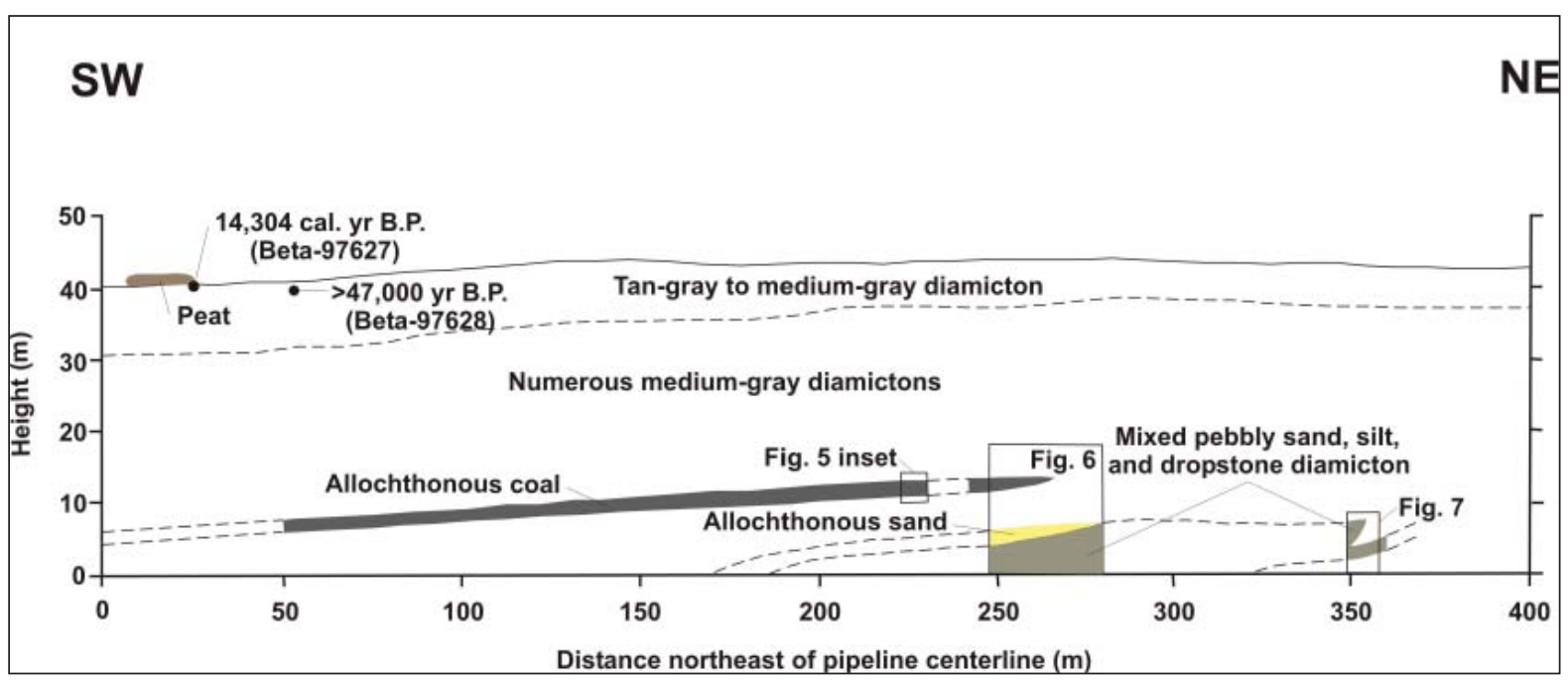

Figure 4. Sketch of section exposed northeast of pipeline centerline in coastal bluff at Granite Point. Vertical exaggeration $=2$. Much of lower section is obscured by a colluvial apron. 
fills in the Beluga Formation), and angular to irregular masses of pebble diamicton (fig. 5). These fragments are suspended in a matrix of crushed coal chaotically mixed with lenses and layers of fine to medium structureless sand. The presence of crushed coal and sand between chunks of coal and sandstone indicates that both formed a slurry during emplacement of the coal. Typically, the disrupted coal is in abrupt contact with an overlying clay-silt diamicton with numerous dropstone pebbles. Abruptly underlying the coal bed is a distinctive, gray (7.5YR6/0), fine to medium sand with 1- to 2-mm-thick lenses of crushed coal. This sand bed is at least $1 \mathrm{~m}$ thick and dries white (10YR8/1). I suggest that the apparent coherent bedlike character of the disrupted coal is a function of its mode of deposition as a discrete subestuarine slide, which probably slid on the underlying sand that was saturated and acted as a lubricating slurry. The presence of late Miocene pollen in the coal fragments and nearby exposures of coal beds in the Beluga Formation indicate the source of the landslide.

Stratigraphically lower and separated from the disrupted coal and its associated underlying sand by a dropstonerich diamicton is a distinctive, 2-m-thick, light-colored, fairly massive, allochthonous sand probably formed by intensive fracturing and pulverizing of sandstone units in the nearby Beluga Formation (fig. 6). The sand is clearly not mixed with diamictons that enclose the deposit. Schmoll and others (1984, fig. 9A) mapped this deposit as sandstone, but the unit is clearly not lithified. In the vicinity of Station 263 NE (fig. 4), the sand is underlain by a series of silt-rich diamicton layers up to $12 \mathrm{~cm}$ thick that contain pebble-sized pieces of dark gray-brown claystone. This claystone is typically interlayered with sandstones in the Beluga Formation in this part of the Cook Inlet basin², indicating that both the sand and silt units represent reworked Beluga Formation. The lack of mixing of both units with surrounding rainout diamictons indicates that the period of their emplacement was brief.

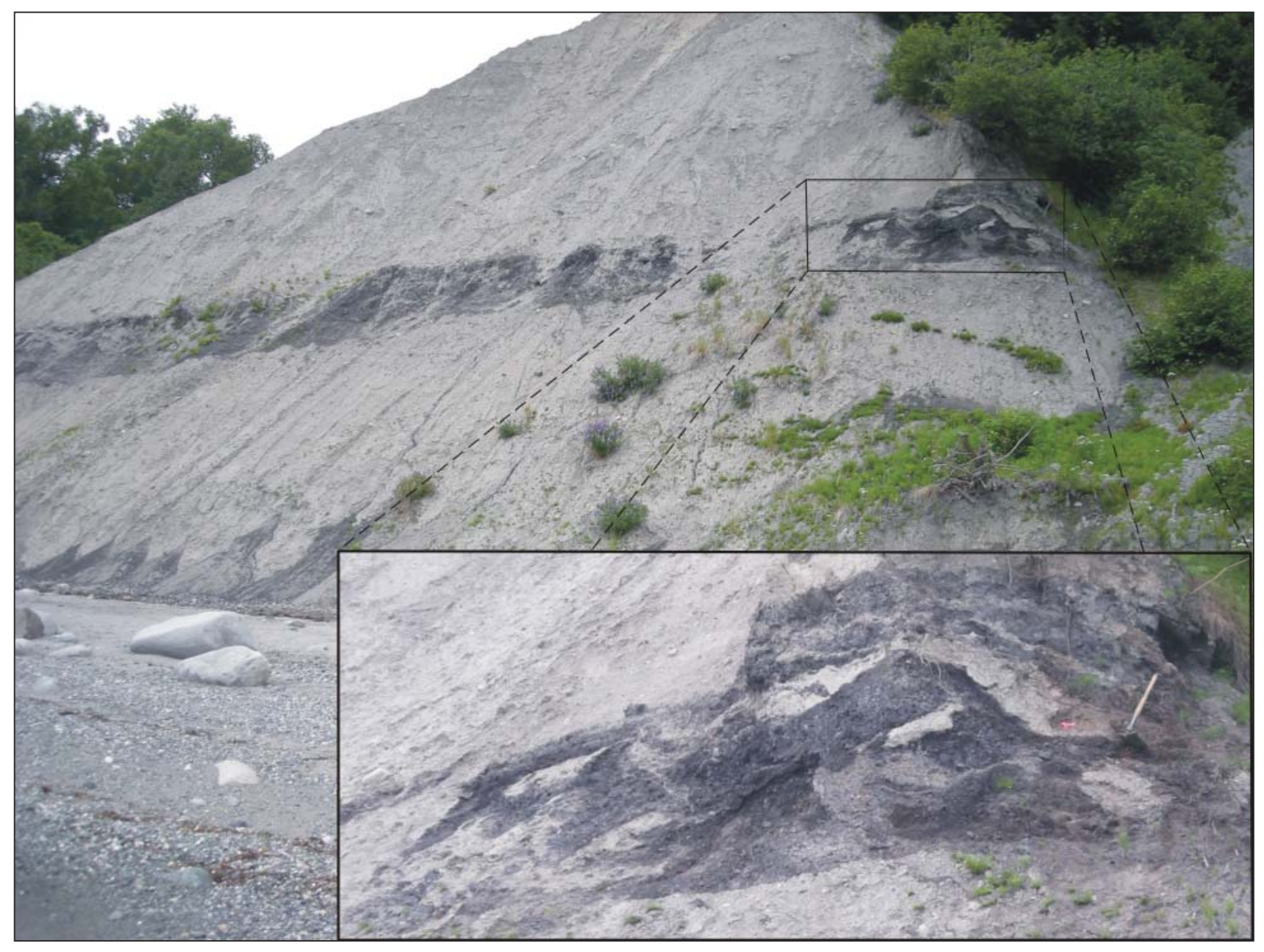

Figure 5. Prominent coal bed exposed in coastal bluff between $~ 150$ and $230 \mathrm{~m}$ northeast of pipeline centerline. Inset shows intensely fractured, pulverized, and distorted allochthonous coal mixed with pebble diamicton. Shovel handle is $0.5 \mathrm{~m}$ long. Photographs taken 07/15/08.

${ }^{2}$ Laura Silliphant, 09/16/08 written communication. The Sterling Formation of Pliocene age, which overlies the Beluga Formation elsewhere in Cook Inlet basin, is not present in the Granite Point-Beshta Bay area and likely is not the source of the allochthonous beds. I suggest that the Sterling Formation was removed by intense glacial scouring in this area prior to deposition of the Kaloa beds. 


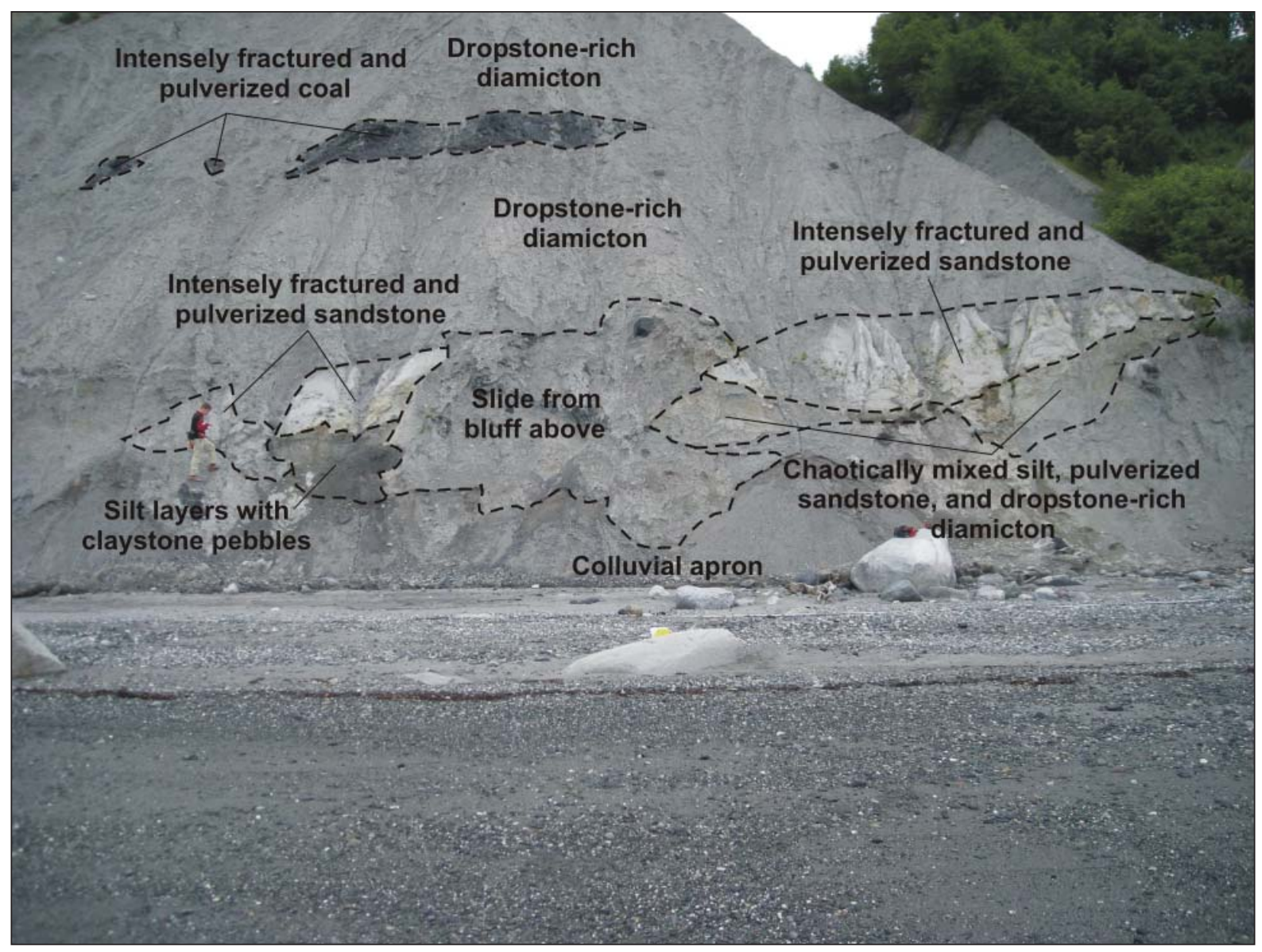

Figure 6. Principal stratigraphic units exposed in coastal bluff 263 mortheast of pipeline centerline are partially obscured by slope colluvium. Person provides scale. Photograph taken 07/16/08.

Supporting evidence for the Beluga Formation as the source of the allochthonous beds is found $\sim 45 \mathrm{~m}$ farther northeast, where pebbly sand contains small lenses of clay with some silt and sand and scattered small cobbles of siderite, which typically forms concretions in the Beluga Formation. The moist color of the sand there is light olive-gray (2.5Y5/4) to yellowish brown (10YR5/6) and the sand comprises the upper part of a series of 30- to 40-cm-thick beds that individually grade from pebble gravels upward into sands. The presence of siderite nodules in these sands and their graded beds indicate that these units were derived from the Beluga Formation and were deposited on the inlet bottom by a series of subestuarine density flows.

Near Station 355 NE (fig. 4), a tan layer of fine to medium sand overlies the chaotically bedded, tan-gray mass of mixed pebbly sand, silt, and dropstone diamicton (fig. 7). The sand bed, which encloses a blocky siderite concretion, may represent a density flow deposit or some sort of dike related to liquefaction after deposition of the lower diamicton, which is the stratigraphically lowest and oldest exposed allochthonous deposit in the bluff section.

Farther northeast, the high bluff section at the southwestern limit of Beshta Bay displays numerous complex diamictons interlayered with planar sand beds (fig. 8), which document deposition of subestuarine flows, slides, and rainout diamictons on the former inlet floor prior to deposition of younger allochthonous beds (Kaloa deposits) to the southwest. Thin sand beds were deposited by bottom currents between episodes of diamicton deposition when ice-proximal turbid plumes shifted locations or glacial or shelf ice drifted away from the site. Apparent flowage of mass-movement units in the section indicates that the inlet bottom sloped southwest.

In Beshta Bay, large onshore landslides displace and expose the Beluga Formation, including emplacement of tilted blocks of fossiliferous sandstone, siltstone, and coal in the intertidal zone (fig. 1). Based on radiocarbon ages of $<200 \mathrm{yr}$ B.P. and growth-ring counts in curved trees, Schmoll and others $(1984$, p. 60) suggested that landsliding continues. The degree of postslide modification is very similar to landslides formed in upper Cook Inlet during the Great Alaska Earthquake of March 27, 1964, and that major seismic event may have produced the landslides in 


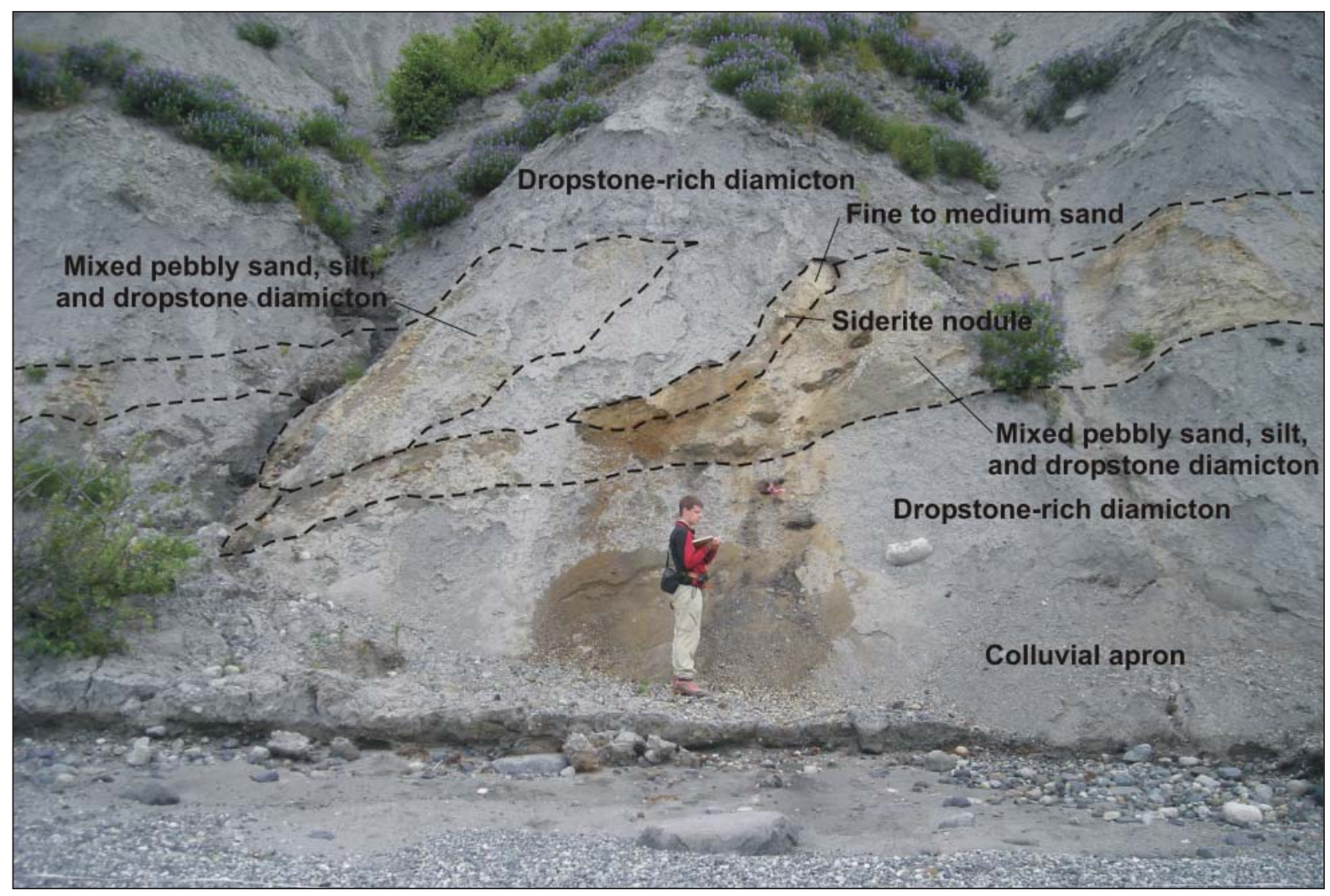

Figure 7. About 355 m northeast of pipeline centerline, a 30-cm-thick, fine to medium tan sand containing clasts of siderite overlies a tan-gray, complexly bedded pebbly sand, silt, and dropstone diamicton sandwiched between massive, medium-gray dropstone-rich diamictons. Person provides scale. Photograph taken 07/16/08.

the Beshta Bay area. Perhaps a more likely source of an earthquake that could have produced these large onshore landslides is an active local fault.

\section{AGE AND DEPOSITIONAL MODEL}

Clearly, the Granite Point-Beshta Bay section is older than the 14,304 cal. yr B.P. age of the basal peat at the top of the section. Early misinterpretation of the bluff section north of Kenai by Karlstrom (1964, pl. 6) was based on several infinite radiocarbon ages of reworked Tertiary wood in much younger glaciofluvial deposits (Reger and others, 2007, fig. 53), and I believe that the single infinite radiocarbon age of $>47,000$ yr B.P. (Beta-97628, Haeussler and others, 2000, table 2) for wood found $1.2 \mathrm{~m}$ below the top of the youngest diamicton at the top of the Granite Point section (fig. 4) does not reflect the age of the enclosing sediments. A diligent search of the bluff section did not reveal the presence of potentially datable calcareous shells or plates of benthic pelecypods, gastropods, and barnacles, like those found in similar diamictons in upper Cook Inlet and at Kenai and Kalifornsky along the west coast of the Kenai Peninsula (Reger and others, 1995, 1996). This lack of datable material forces use of less precise, indirect dating of the Kaloa deposits by relating the sequence of events in the Granite Point area to events elsewhere in the Cook Inlet region.

Lengthy investigations of Quaternary deposits in the Cook Inlet region produced a model for the last major glaciation, termed the Naptowne glaciation (Reger and others, 2007), which is patterned after an earlier model developed by Karlstrom (1964). During this glaciation, massive, glaciers initially coalesced to form the Cordilleran Ice Sheet in the Alaska Range west of Granite Point and flowed eastward into the Cook Inlet trough. Scouring by this thickening glacier complex was intense on the west side of Cook Inlet, and the products of erosion were carried eastward and southeastward to be deposited on and near the northwestern Kenai Peninsula. The Naptowne glaciation climaxed $~ 23,000$ years ago during the earliest recognized (Moosehorn) stade and then declined (Reger and others, 2007, fig. 6). Ice from the thinning and receding glacier complex last reached the northwestern Kenai 


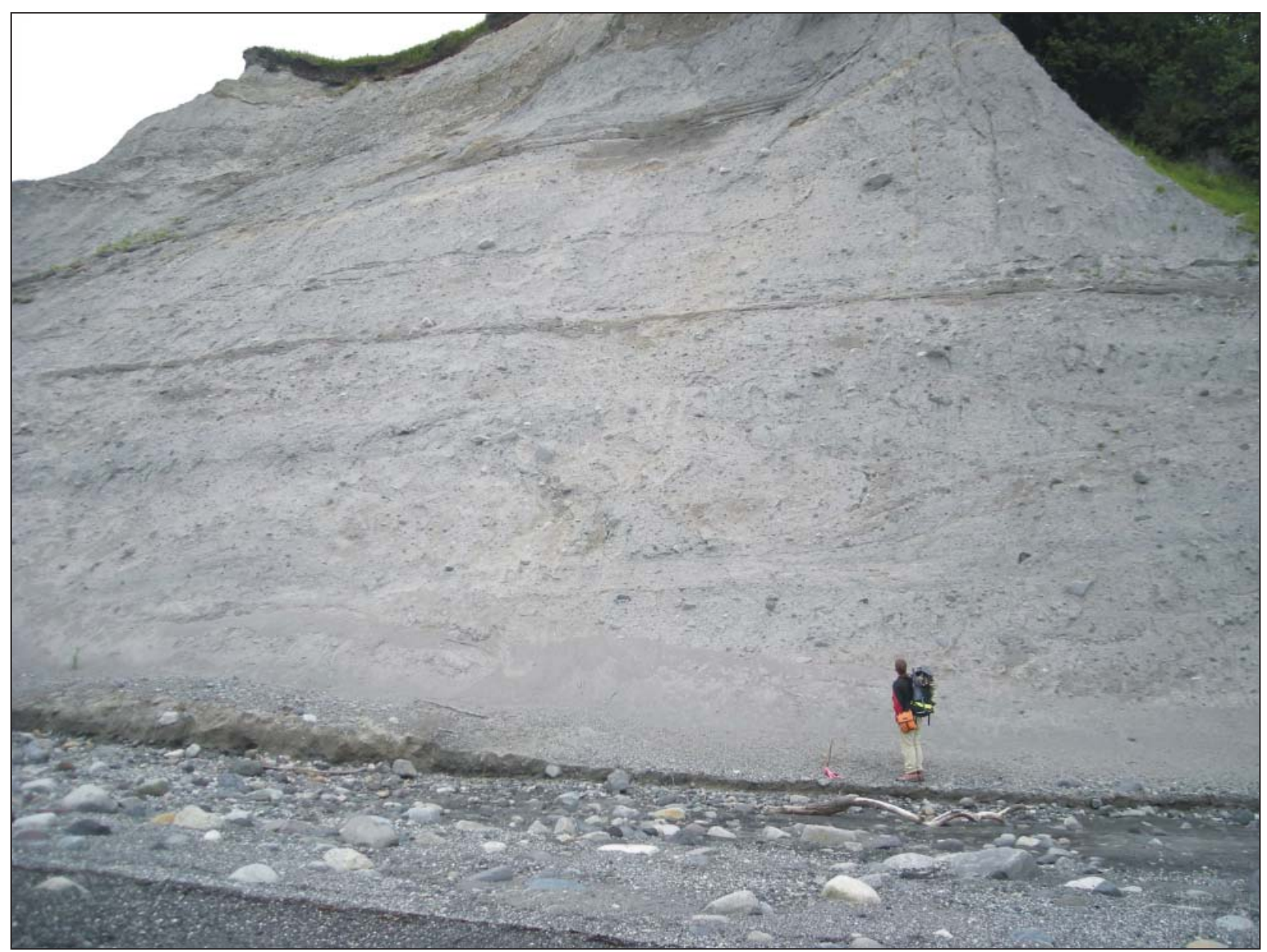

Figure 8. The coastal bluff at the southwestern end of Beshta Bay displays complexly deformed diamictons interlayered with sand beds. This section documents deposition of subestuarine flows, slides, and rainout diamictons on the former inlet floor prior to deposition of the sequence of allochthonous beds in the coastal bluff to the southwest. Person provides scale. Photograph taken 07/16/08.

Peninsula during the second (Killey) stade of the Naptowne glaciation, and then subsequently retreated back across ancestral Cook Inlet, permitting egress of estuarine waters from south of the Nikiski area into the upper Cook Inlet basin 17,500 years ago (Reger and others, 1995, 2008). During the last two stades (Skilak and Elmendorf) of the Naptowne glaciation, tidewater glaciers spawned ice shelves that fluctuated near the present west coast of Cook Inlet, which was still isostatically depressed by the mass of the thick early Naptowne ice sheet, before receding back into their mountainous source areas. The Naptowne glaciation ended 11,000 years ago.

A key indication of the general age of the Kaloa sequence is the lack of evidence in the section for grounding of glacial or shelf ice in the Granite Point area. None of the diamictons exhibit the intense deformation or deposits typical of morainal-bank complexes produced by contact of glacial ice with the inlet bottom (Eyles and McCabe, 1989, fig. 10; Reger and others, 2007, figs. 53 and 55). Except for mass-movement deposits, diamictons in the section accumulated rapidly as rainout deposits beneath floating tidewater glaciers, ice shelves, or ice-proximal turbid plumes. ${ }^{3}$ Thus, the diamicton that was mapped across the top of the section as Nikolai ground moraine by Schmoll and others (1984, fig. 9A), is glacioestuarine, not a morainal deposit. Instead, deep inlet conditions existed in this area during deposition of most of the Kaloa section, and tidewater glaciers or ice shelves were thin enough to float freely. The presence of tan-gray diamicton, thin beds and lenses of sand, and tidal-flat deposits at the top of the the Kaloa section indicates that shoaling and emergence of the rebounding inlet bottom occurred late in

${ }^{3}$ Typically, rates of sedimentation proximal to tidewater glaciers are high (Cowan and Powell, 1991). I suggest that deposition was sufficiently rapid beneath former tidewater glaciers or ice shelves in the Granite Point area that benthic organisms could not survive, perhaps explaining the lack of their remains in the deposits there. 
the sequence of events. These conditions likely existed late in the Naptowne glaciation, probably during the late Skilak and Elmendorf stades, roughly 16,500 to 11,000 years ago (Reger and others, 2007, fig. 6). Therefore, based on environment of deposition and estimated age, the Kaloa section probably correlates with younger Bootlegger Cove Formation deposits in the Anchorage area (Schmoll and others, 1972, 1984, 1999; Reger and others, 1995) and postdates older Bootlegger Cove Formation deposits in the Kenai-Kalifornsky area (Reger and Pinney, 1997; Reger and others, 1996, 2008).

The proximity of the Granite Point-Beshta Bay section to the Granite Point anticline has long been recognized (Magoon and others, 1976, pl. 1; Schmoll and others, 1984, p. 58). Offshore platforms Bruce and Anna tap oil that has accumulated in the Granite Point anticline (Magoon and others, 1976, pl. 1) (fig. 1). Beluga Formation exposed in the headwalls of onshore landslides in the Beshta Bay area is thinly buried on the northwestern flank of the Granite Point structure (fig. 1). Haeussler and others (2000, fig. 7) attributed dipping strata in the Kaloa package on the western flank of the anticline to growth of the Granite Point anticline, and, as previously stated, they favored a Pleistocene age for emplacement of the allochthonous coal in the Kaloa sequence. Large onshore landslides in the Beshta Bay area indicate that the nearsurface Beluga Formation in that area is susceptible to slope failure, perhaps indicating a mechanism for the emplacement of allochthonous beds on the western flank of the Granite Point anticline. At a time when the floor of Cook Inlet was isostatically depressed and tidewater glaciers and associated ice shelves related to the Chakachatna River-McArthur River lobe floated in the Granite Point area, sudden displacements along faults in the growing Granite Point anticline may have produced episodic, locally intense shaking that dislodged submerged nearsurface beds of the folded Beluga Formation, triggering subestuarine slides and density flows that moved rapidly down the western flank of the structure (fig. 9). At least two episodes of severe shaking between $\sim 16,500$ and $\sim 11,000$ years ago are indicated by the allochthonous beds sandwiched between diamictons in the Kaloa sequence, implying that the Granite Point structure is actively growing.

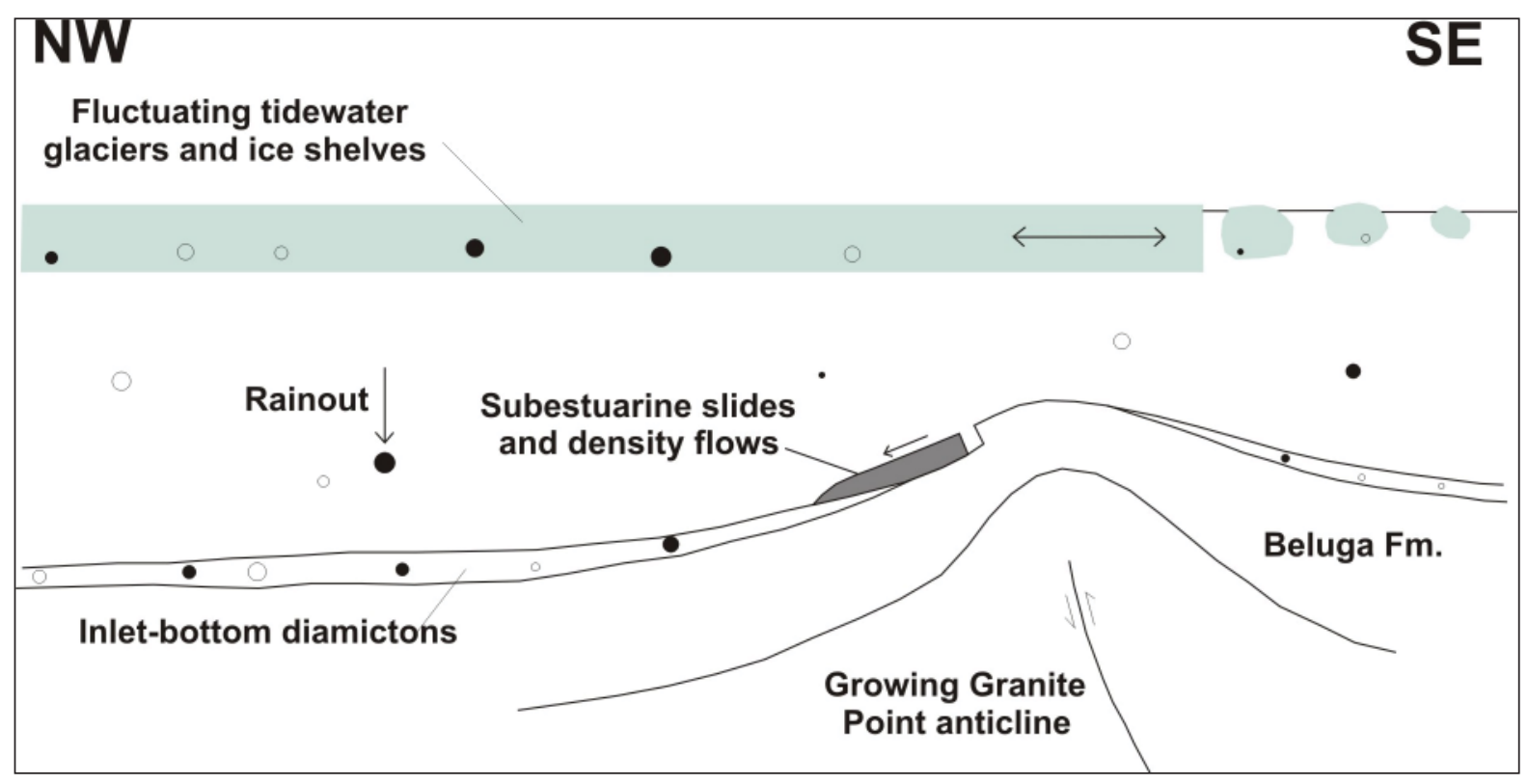

Figure 9. Environment beneath fluctuating tidewater glaciers and ice shelves during deposition of Kaloa sediments on the western flank of the growing Granite Point anticline between Granite Point and Beshta Bay.

\section{ACKNOWLEDGMENTS}

Funding for logistical support was provided by the Alaska Division of Geological \& Geophysical Surveys. The concepts presented in this report were developed along the beach during discussions with other members of the DGGS field party, including (in alphabetical order) Emily Finzel, Bob Gillis, Ken Helmold, Dave LePain, Jake Mongrain, Shawn Peterson, Ken Ridgeway, Laura Silliphant, Rick Stanley, and Marwan Wartes. I recall that Ken Ridgeway first suggested the idea of landsliding off the western flank of the Granite Point structure as a possible 
mechanism for emplacement of the unique allochthonous beds in the Kaloa sequence. I am grateful to all of these colleagues for freely sharing their individual insights. However, errors of interpretation and presentation remain my responsibility. I greatly appreciate the review by Dave LePain, who provided very helpful suggestions that improved this report.

\section{REFERENCES}

Boss, R.F., Lennon, R.B., and Wilson, B.W., 1976, Middle Ground Shoal oil field, Alaska, in Braunstein, J., ed., North American oil and gas fields: American Association of Petroleum Geologists Memoir 24, p. 1-22.

Cowan, E.A., and Powell, R.D., 1991, Ice-proximal sediment accumulation rates in a temperate glacial fjord, southeastern Alaska, in Anderson, J.B., and Ashley, G.M., eds., Glacial marine sedimentation; Paleoclimatic significance: Geological Society of America Special Paper 261, p. 61-73.

Eyles, Nicholas, and McCabe, A.M., 1989, The late Devensian (<22,000 B.P.) Irish Sea basin: The sedimentary record of a collapsed ice sheet margin: Quaternary Science Reviews, v. 8, p. 307-351.

Haeussler, P.J., Bruhn, R.L., and Pratt, T.L., 2000, Potential seismic hazards and tectonics of the upper Cook Inlet basin, Alaska, based on analysis of Pliocene and younger deformation: Geological Society of America Bulletin, v. 112, no. 9, p. 1,414-1,429.

Karlstrom, T.N.V., 1964, Quaternary geology of the Kenai Lowland and glacial history of the Cook Inlet region, Alaska: U.S. Geological Survey Professional Paper 443, 69 p., 6 map sheets, various scales.

Magoon, L.B., Adkison, W.L., and Egbert, R.M., 1976, Map showing geology, wildcat wells, Tertiary plant fossil localities, K-Ar age dates, and petroleum operations, Cook Inlet, Alaska: U.S. Geological Survey Miscellaneous Investigations Map I-1019, 3 map sheets, scale 1:250,000.

Reger, R.D., and Pinney, D.S., 1997, Last major glaciation of Kenai Lowland, in Karl, S.M., Vaughn, N.R., and Ryherd, T.J., eds., 1997 guide to the geology of the Kenai Peninsula, Alaska: Anchorage, Alaska Geological Society guidebook, p. 54-67.

Reger, R.D., Combellick, R.A, and Brigham-Grette, Julie, 1995, Update of latest Wisconsin events in the upper Cook Inlet region, southcentral Alaska, in Combellick, R.A, and Tannian, Fran, eds., Short Notes on Alaska Geology 1995: Alaska Division of Geological \& Geophysical Surveys Professional Report 111, p. 45-53.

Reger, R.D., Pinney, D.S., Burke, R.M., and Wiltse, M.A., 1996, Catalog and preliminary analyses of geologic data related to middle to late Quaternary deposits, eastern and northern Cook Inlet region, Alaska: Alaska Division of Geological \& Geophysical Surveys Report of Investigations 95-6, 188 p., 5 map sheets, scale 1:250,000.

Reger, R.D., Sturmann, A.G., Berg, E.E., and Burns, P.A.C., 2007, A guide to the late Quaternary history of northern and western Kenai Peninsula, Alaska: Alaska Division of Geological \& Geophysical Surveys Guidebook 8, 112 p., 6 map sheets, scale 1:63,360.

Schmoll, H.R., and Yehle, L.A., 1978, Generalized physiography and geology of the Beluga coal field and vicinity, south-central Alaska, in Johnson, K.M., ed., The United States Geological Survey in Alaska: Accomplishments during 1977: U.S. Geological Survey Circular 772-B, p. B73-B76.

1986, Pleistocene glaciation of the upper Cook Inlet basin, in Hamilton, T.D., Reed, K.M., and Thorson, R.M., eds., Glaciation in Alaska-the geologic record: Anchorage, Alaska Geological Society, p. 193-218.

Schmoll, H.R., Chleborad, A.F., Yehle, L.A., and Gardner, C.A., 1981, Reconnaissance engineering geology of the Beluga coal resource area, southcentral Alaska, in Rao, P.D., and Wolff, E.N., eds., Focus on Alaska's coal '80: Fairbanks, University of Alaska Mineral Industries Research Laboratory Report 50, p. 92-110.

Schmoll, H.R., Szabo, B.J., Rubin, Meyer, and Dobrovolny, Ernest, 1972, Radiometric dating of marine shells from the Bootlegger Cove Clay, Anchorage, Alaska: Geological Society of America Bulletin, v. 83, no. 4, p. 1,107-1,114.

Schmoll, H.R., Yehle, L.A., Gardner, C.A., and Odum, J.K., 1984, Guide to surficial geology and glacial stratigraphy in the upper Cook Inlet basin: Anchorage, Alaska Geological Society guidebook, 89 p.

Schmoll, H.R., Yehle, L.A., and Updike, R.G., 1999, Summary of Quaternary geology of the Municipality of Anchorage, Alaska: Quaternary International, v. 60, p. 3-36. 